\title{
Erratum to: Interleukin-1 beta-induced reduction of tissue water diffusion in the juvenile rat brain on ADC MRI is not associated with ${ }^{31} \mathrm{P}$ MRS-detectable energy failure
}

Raman Saggu

Unfortunately, after publication of this article [1], it was noticed that Fig. 1b (Fig. 1 here) is incorrect. The corrected figure can be seen below.

Received: 9 May 2016 Accepted: 11 May 2016

Published online: 23 May 2016

\section{Reference}

1. Saggu R. Interleukin-1 beta-induced reduction of tissue water diffusion in

the juvenile rat brain on ADC MRI is not associated with ${ }^{31} \mathrm{P}$ MRS-detectable energy failure. J Inflamm. 2016;13:9. doi:10.1186/s12950-016-0118-3.

\footnotetext{
Submit your next manuscript to BioMed Central and we will help you at every step:

- We accept pre-submission inquiries

- Our selector tool helps you to find the most relevant journal

- We provide round the clock customer support

- Convenient online submission

- Thorough peer review

- Inclusion in PubMed and all major indexing services

- Maximum visibility for your research
}

Submit your manuscript at

www.biomedcentral.com/submit 


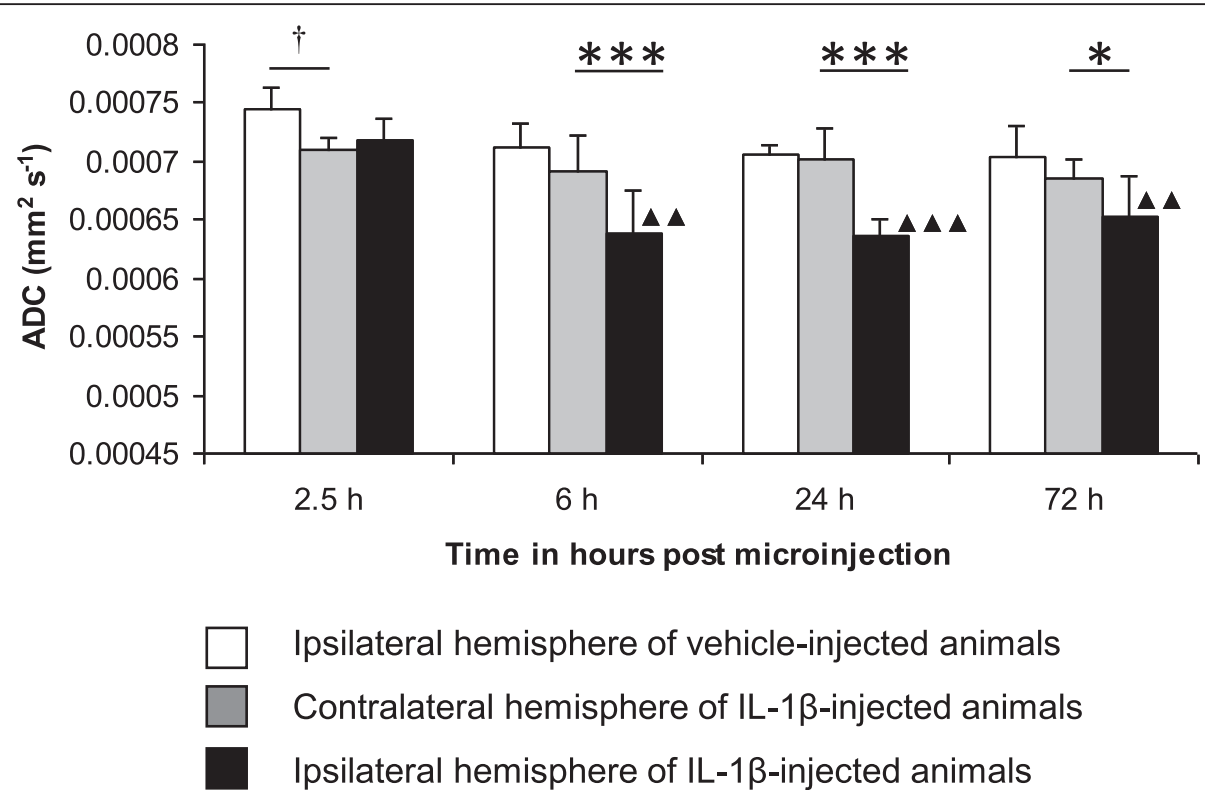

Fig. 1 Time course of MRI changes following intrastriatal microinjection of $100 \mathrm{ng} / \mu \mathrm{l} I L-1 \beta$. ADC changes determined by thresholding. Mean $A D C$ (error bars indicate a 1 SD) within the ipsilateral or contralateral striatum. Statistical significance indicated by *** $p<0.001,{ }^{*} p<0.05$; paired $t$-test, $+p<0.05$; unpaired $t$-test and $\boldsymbol{\Delta} \boldsymbol{\Delta} \boldsymbol{\Delta} p<0.001$, $\boldsymbol{\Delta} \boldsymbol{\Delta} p<0.01$; one-way ANOVA, post-testing using Bonferroni multiple comparisons test, with respect to the $A D C$ of the IL-1 $\beta$-injected hemisphere at $2.5 \mathrm{~h}$ 